\title{
Travellers' Tales of Wonder
}


In memory of my mother Ruth Laurence

16 July 1954 - 21 September 2001

And for my grandparents

Christopher and Margaret Laurence 


\section{Travellers' Tales of Wonder}

Chatwin, Naipaul, Sebald

Simon Cooke 
(C) Simon Cooke, 2013

Edinburgh University Press Ltd

22 George Square, Edinburgh EH8 9LF

www.euppublishing.com

Typeset in $10.5 / 13$ pt Sabon

by Servis Filmsetting Ltd, Stockport, Cheshire, and

printed and bound in Great Britain by

CPI Group (UK) Ltd, Croydon CR0 4YY

A CIP record for this book is available from the British Library

ISBN 9780748675463 (hardback)

ISBN 9780748675470 (webready PDF)

ISBN 9780748675487 (epub)

ISBN 9780748675494 (Amazon ebook)

The right of Simon Cooke

to be identified as author of this work

has been asserted in accordance with

the Copyright, Designs and Patents Act 1988. 